\title{
THE FEATURES OF ARTERIAL THYMUSATNALBUPHINEACTION
}

\author{
Tatyana Harapko \\ Department of Human Anatomy and Histology \\ Uzhhorod National University \\ 22 Victory str., Transcarpathian region, Uzhhorod, Ukraine, 88015 \\ garapko-tvm@mail.ru \\ Andrew Holovatsky \\ Department of Human Anatomy and Histology \\ Uzhhorod National University, MD, professor \\ 22 Victory str., Transcarpathian region, Uzhhorod, Ukraine, 88015 \\ holand36@ukr.net
}

\begin{abstract}
The article presents and analyzes the results of the pilot study, at which opioid nalbuphine was daily administered in white rats-males of reproductive age (1,5-3,5 - month) for six weeks and one week after discontinuation of therapy. The drug "nalbuphine" was injected intraperitoneally daily 1 per day over 42 days. The data were compared with a control group of intact animals. The study was conducted on 52 animals, which were divided into eight groups.

Morphometric study was performed using a system of visual analysis of histological preparations. Dynamics of changes in the external and internal diameters of medium caliber arteries thymus, media and lumen area, Vohenvorta ratio was studied.

The increase of the external diameter and reduction of the internal diameter of the medium caliber arteries, increase of the area of media, increase of the area of the lumen, increase of the Vohenvortaratio.The blood vessels are dilated, gaps filled elements of the blood vessels around the swelling, the process of vascular sclerosis.
\end{abstract}

Keywords: artery, experiment, rat, nalbuphine, thymus.

\section{Introduction}

Urgent social and medical issues of our time are opioid addiction [1-3]. Opioids have been used in medicine for therapeutic purposesfor a long time. Representative opioid is nalbuphine (nubain) a narcotic analgesic, semi-synthetic opioid derived phenanthrene [4].

The effect of opioids on the organs of the immune system is insufficiently studied, particularly at primary lymphoid organs, the thymus. In the special literature there are data about influence on the structural organization of the thymus various harmful factors $[5,6]$ such as indomethacin, histynat, methyl alcohol, naloxone, hyperosmolar solution [7], imunofan [8], cyclophosphamide [9-11] but there are only a few data on the impact of drugs in this important primary lymphoid organs. Application of imunofan has the pronounced effect on the maturation and differentiation of thymocytes in the thymus of rats of reproductive age [12]. After 1 day after administration of immunosuppressive cyclophosphamide there takes place the breachof hematotymusnoho permeability barrier [13, 14]. Within 30 days after administration of cyclophosphamide differences in the structure of rat thymus substantially leveled [15]. The data on the effect of opioids on the cerebellum, pancreas, tongue, eyeball, skin, cerebrumwere published [16-18].

The thymus as the primary organ of the immune system provides antigen independent proliferation and differentiation of a subpopulation of $\mathrm{T}$ lymphocytes. The exterior is covered with a connective tissue capsule that gives partitions into the parenchyma, dividing it into segments. Each particle consists of cortex and medulla. 


\section{Aim of the research}

To study the dynamic changes of structural parameters of medium caliber arteries thymus during a six-week action of nalbuphine experiment.

\section{Materials and Methods}

The study was conducted on 52 white male rats weighing $80-150$ grams of reproductive age (1,5-3,5 - month; middle age - 2,5 - month).

Experimental animals were divided into 8 groups of 5 animals (Table 1). 12 white males served as the control rats thatwere injected with $0.9 \%$ sodium chloride solutioninstead of nalbuphine.

Morphometric study was performed using a system of visual analysis of histological preparations. Image of histological preparations on a computer monitor was taken out of the microscope MICROmed SEO SSAN using the camera Vision CCD Camera. Morphometric study was conducted using software VideoTesT-5.0 KAAr Image Base and Microsoft Excel on a personal computer in the histological preparations stained with hematoxylin and eosin. We determined the outer and inner diameter of medium caliber arteries thymus, the average area of membrane and lumen of the vessel, the Vohenvortaratio. Digitally statistically processed values presented the average and standard deviation $(\mathrm{M} \pm \mathrm{m})$. Probability differences of average values ( $\mathrm{p}$ ) were determined by Student's test. Differences were considered likely at $\mathrm{p}<0,05$.

The drug "nalbuphine" was daily injected intraperitoneally (10-11 am) 1 per day over 42 days (6 weeks). Every week dose of nalbuphine injections was increased (Table 1) according to recommendations [19].

Table 1

Doses of the drug nalbuphine experimental animals

\begin{tabular}{|c|c|c|c|c|c|c|c|c|}
\hline $\begin{array}{l}\text { Indices, the } \\
\text { duration of the } \\
\text { experiment }\end{array}$ & $\begin{array}{l}\text { I group } \\
\text { intact } \\
\text { animals }\end{array}$ & $\begin{array}{l}\text { II group, } \\
1 \text { week }\end{array}$ & $\begin{array}{l}\text { III group, } \\
2 \text { weeks }\end{array}$ & $\begin{array}{l}\text { IV group, } \\
3 \text { weeks }\end{array}$ & $\begin{array}{l}\text { V group, } \\
4 \text { weeks }\end{array}$ & $\begin{array}{l}\text { VI group, } \\
5 \text { weeks }\end{array}$ & $\begin{array}{l}\text { VII group, } \\
6 \text { weeks }\end{array}$ & $\begin{array}{c}\text { VIII group, } \\
1 \text { week after } \\
\text { disconti-nuation }\end{array}$ \\
\hline $\begin{array}{c}\text { The average } \\
\text { weight of rats, } g\end{array}$ & 76 & 80 & 94 & 105 & 115 & 129 & 137 & 142 \\
\hline Dose, $\mathrm{mg} / \mathrm{kg}$ & - & 8 & 15 & 20 & 25 & 30 & 35 & - \\
\hline
\end{tabular}

Based on the cooperation agreement between the Department of Human Anatomy and Histology of the Medical Faculty SHEE "Uzhhorod National University" and the Department of Anatomy Lviv National Medical University named Danylo Galician, research conducted at the Lviv National Medical University. D. Galician All the animals were kept in vivarium conditions of Lviv National Medical. Experiments were conducted under the provisions of the "European Convention for the protection of vertebrate animals used for experimental and other scientific purposes" (Strasbourg, 1986) [20], Council Directive 86/609 / EEC (1986) [21], the Law of Ukraine №3447-IV “On protection of animal" treatment common ethical animal experimentation adopted the first national Congress on bioethics Ukraine (2001) [22].

\section{Results}

The dynamics of changes in the external and internal diameters of medium caliber arteries was studied. The gradual increaseof external diameter in maximum 5 weeks and of internal diameter in 1 week was revealed. Further performance decreases (Table 2).

Results of Table 1 are shown schematically in Fig. 1. We can see the dynamics of internal and external diameters of medium caliber arteries during the experiment. 
Table 2

Dynamics of changes in the external and the internal diameter of the arteries medium caliber thymus of white rat control and experimental groups $(\mathrm{M} \pm \mathrm{m})$

\begin{tabular}{|c|c|c|}
\hline Group, term experiment & $\begin{array}{l}\mathrm{D}^{1} \text { (micrometer) outside } \\
\text { diameter arteries }\end{array}$ & $\begin{array}{l}D^{2} \text { (micrometer) internal } \\
\text { diameter arteries }\end{array}$ \\
\hline The first group intact animals & $50,70 \pm 1,87$ & $25,89 \pm 1,65$ \\
\hline $\begin{array}{l}\text { The second group } \\
\text { 1 week }\end{array}$ & $53,28 \pm 1,14$ & $26,75 \pm 1,95$ \\
\hline $\begin{array}{l}\text { The third group } \\
2 \text { weeks }\end{array}$ & $52,97 \pm 1,76$ & $26,49 \pm 2,03$ \\
\hline $\begin{array}{l}\text { The fourth group } \\
3 \text { weeks }\end{array}$ & $52,77 \pm 1,18$ & $23,17 \pm 1,52$ \\
\hline $\begin{array}{l}\text { The fifth group } \\
4 \text { weeks }\end{array}$ & $54,76 \pm 1,97$ & $22,97 \pm 1,23$ \\
\hline The sixth group 5 weeks & $56,14 \pm 1,98$ & $23,75 \pm 2,02$ \\
\hline $\begin{array}{l}\text { The seventh group } \\
6 \text { weeks }\end{array}$ & $55,83 \pm 1,16$ & $22,11 \pm 1,87$ \\
\hline $\begin{array}{l}\text { The eighth group } \\
1 \text { week after discontinuation }\end{array}$ & $52,88 \pm 1,53$ & $22,07 \pm 1,57$ \\
\hline
\end{tabular}

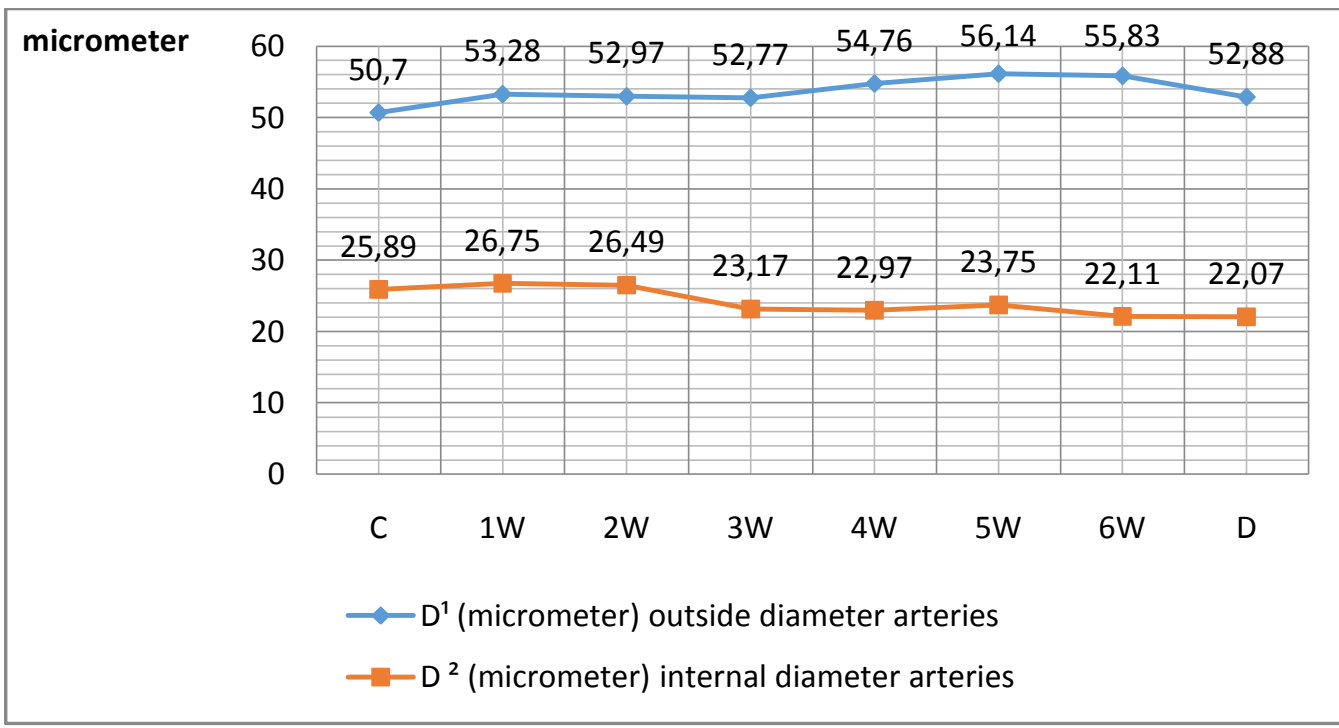

Fig. 1. Dynamics of internal and external diameters of the medium caliber arteries thymus in white rats of control and experimental groups: $\mathrm{C}$ - the first, intact animals; $1 \mathrm{~W}$ - the second group of animals after 1 week of opioid exposure; $2 \mathrm{~W}$ - the third group of animals after 2 weeks of opioid exposure; $3 \mathrm{~W}$ - the fourth group of animals after 3 weeks of opioid exposure; $4 \mathrm{~W}$ - fifth group of animals after 4 weeks of opioid exposure; $5 \mathrm{~W}$ - sixth group of animals 5 weeks of opioid exposure; $6 \mathrm{~W}$ - seventh group of animals at 6 weeks opioid of exposure; D - eighth group of animals 1 week after discontinuation of opioid

The dynamics of changes in the area of media and lumen area, Vohenvorta ratio in arteries of medium caliber. There was revealed a gradual increase, with a maximum of 5 weeks in the area of media and after 2 week in the lumen area. Further performance decreases (Table 3). 
Table 3

Morphometric parameters arteries of medium caliber thymus in white rats of control and experimental groups $(\mathrm{M} \pm \mathrm{m})$

\begin{tabular}{|c|c|c|c|}
\hline Group, term experiment & $\begin{array}{l}\mathrm{Sm}\left(\mathbf{m} \mathbf{k m}^{2}\right)- \\
\text { media area }\end{array}$ & $\begin{array}{l}\text { SI }\left(\mathbf{m k m} \mathbf{m}^{2}\right)- \\
\text { lumen area }\end{array}$ & Vohenvorta ratio (\%) \\
\hline The first group intact animals & $1436,29 \pm 18,43^{* * *}$ & $514,70 \pm 7,41$ & $290,60 \pm 5,04$ \\
\hline $\begin{array}{l}\text { The second group } \\
\text { 1 week }\end{array}$ & $1571,61 \pm 16,73^{* * *}$ & $546,57 \pm 6,26^{* *}$ & $287,54 \pm 5,98$ \\
\hline $\begin{array}{l}\text { The third group } \\
2 \text { weeks }\end{array}$ & $1593,73 \pm 14,87 * * *$ & $551,75 \pm 7,54 * * *$ & $288,85 \pm 4,09$ \\
\hline $\begin{array}{l}\text { The fourth group } \\
3 \text { weeks }\end{array}$ & $1635,45 \pm 16,76^{* * *}$ & $540,59 \pm 4,87 * *$ & $302,53 \pm 5,78$ \\
\hline $\begin{array}{l}\text { The fifth group } \\
4 \text { weeks }\end{array}$ & $1734,57 \pm 20,13^{* * *}$ & $532,31 \pm 5,95$ & $325,86 \pm 4,77 * * *$ \\
\hline The sixth group 5 weeks & $1763,87 \pm 16,74 * * *$ & $543,68 \pm 6,15^{* *}$ & $324,43 \pm 6,89 * * *$ \\
\hline $\begin{array}{c}\text { The seventh group } \\
6 \text { weeks }\end{array}$ & $1742,73 \pm 14,78^{* * *}$ & $538,78 \pm 5,32 *$ & $323,46 \pm 5,32 * * *$ \\
\hline $\begin{array}{c}\text { The eighth group } \\
1 \text { week after discontinuation }\end{array}$ & $1686,34 \pm 15,72 * * *$ & $535,30 \pm 4,65^{*}$ & $315,03 \pm 4,67 * * *$ \\
\hline
\end{tabular}

Note: values that are statistically significantly different from the ones of the intact group of animals: ${ }^{*}-p<0.05 ; * *-p<0.01 ; * * *-p<0.001$

Table 2 is shown schematically in Fig. 2. You can see the dynamics of the media area and lumen area of medium-caliber arteries during the experiment.

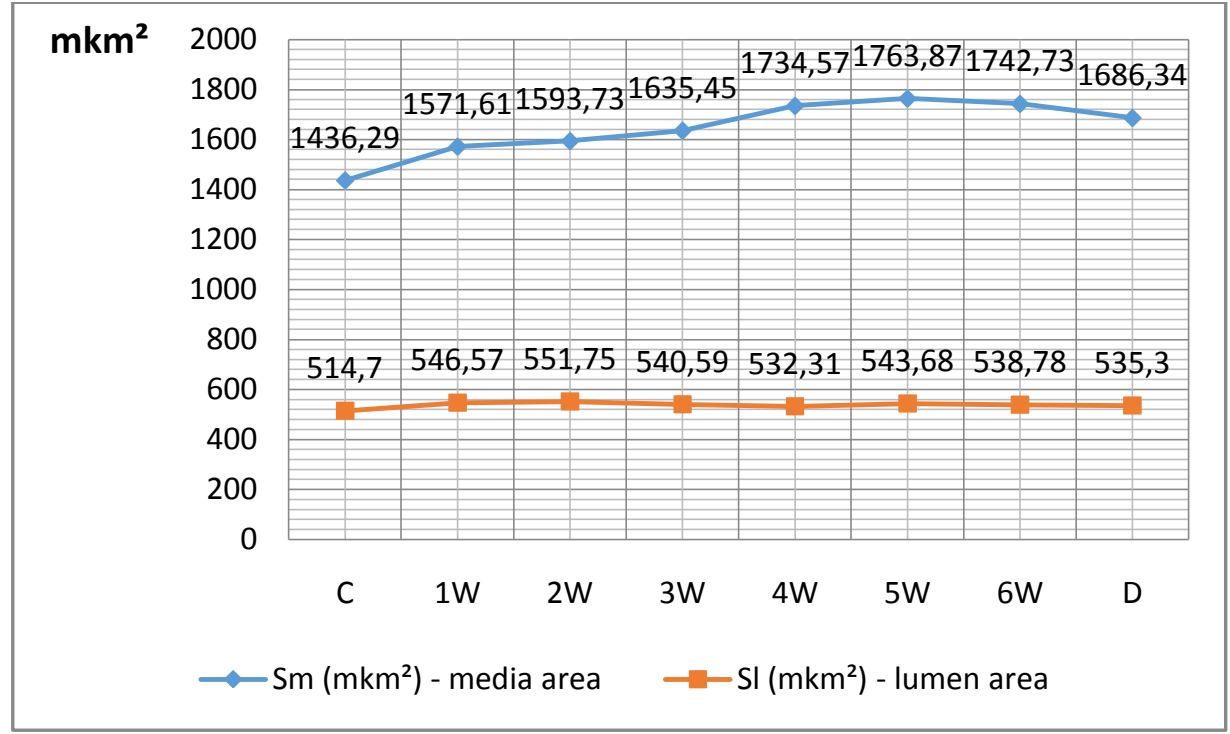

Fig. 2. Dynamics of media and lumen area of medium caliber arteries thymus in white rats of control and experimental groups: $\mathrm{C}$ - the first, intact animals; $1 \mathrm{~W}$ - the second group of animals after 1 week of opioid exposure; $2 \mathrm{~W}$ - the third group of animals after 2 weeks of opioid exposure; $3 \mathrm{~W}$ - the fourth group of animals after 3 weeks of opioid exposure; $4 \mathrm{~W}$ - fifth group of animals after 4 weeks of opioid exposure; $5 \mathrm{~W}$ - sixth group of animals 5 weeks of opioid exposure; $6 \mathrm{~W}$ - seventh group of animals at

6 weeks of opioid exposure; D - eighth group of animals 1 week after discontinuation of opioid

Fig. 3 shows the change vohenvortaratio. Maximum values were recorded after 4 weeks of the experiment. 


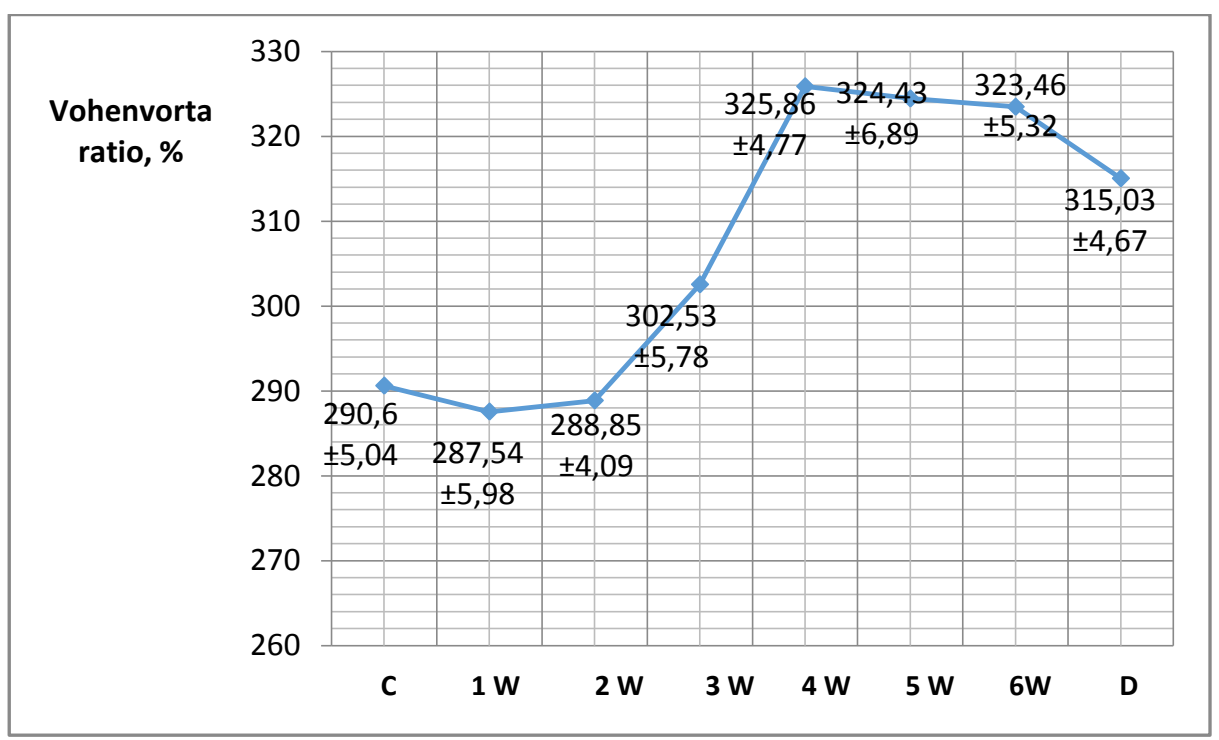

Fig. 3. Dynamics of Vohenvorta ratio of the medium caliber arteries thymus in white rats of control and experimental groups: $\mathrm{C}$ - the first, intact animals; $1 \mathrm{~W}$ - the second group of animals after 1 week of opioid exposure; $2 \mathrm{~W}$ - the third group of animals after 2 weeks of opioid exposure; $3 \mathrm{~W}$ - the fourth group of animals after 3 weeks of opioid exposure; $4 \mathrm{~W}$ - fifth group of animals after 4 weeks of opioid exposure; $5 \mathrm{~W}$ - sixth group of animals 5 weeks of opioid exposure; $6 \mathrm{~W}$ - seventh group of animals at

6 weeks of opioid exposure; D - eighth group of animals 1 week after discontinuation of opioid

On histological preparations were analyzed the microscopic changes in thymic medulla slices of intact white-male rats (Fig. 4, a) before and after 1 week of introduction of nalbuphine (Fig. 4, b). No significant changes were detected.

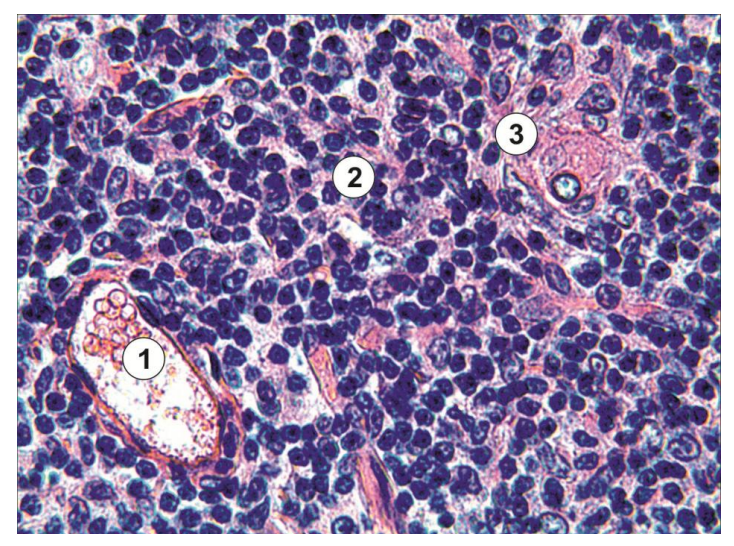

$a$

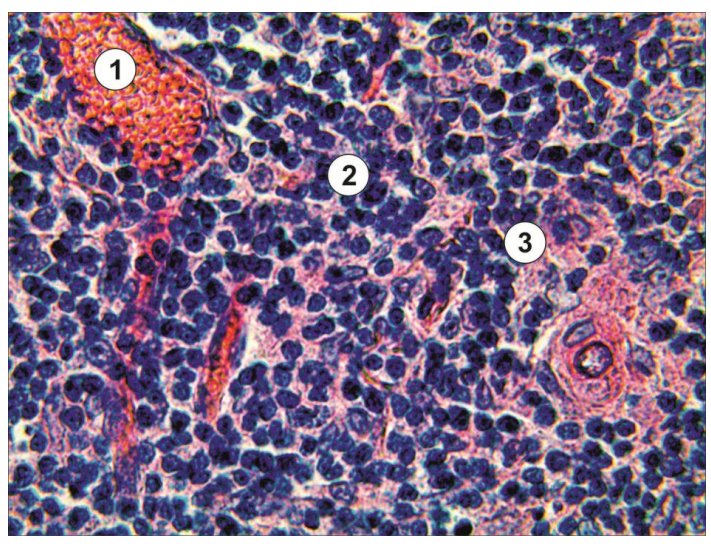

$b$

Fig. 4. Microscopic changes in the medulla of the thymus lobes: $a$-intact white-male rat; $b$ - white-male rat after 1 week of introduction of nalbuphine. Filled with blood venules (1);

2 - T lymphocytes; 3 - Hassalya corpuscle.Stained with hematoxylin and eosin. Coll.: lens $\times 40$, glasses $\times 15$

There was analyzed the microscopic state of the cortex slices thymus ofanimals after three weeks of the experiment. The discovered was expanded and filled with thebloodveins (Fig. 5).

After five weeks of the experiment were revealed many microscopic changes in the cortex slices thymus of animals. Plot thickened interlobular connective tissue, indicating leukocyte diapedesis through the wall of venules; expanded and filled with blood vessels (Fig. 6).

A week after discontinuation microscopic changes in the thymic cortex slices of animals are not returned to normal. Pathological process, developed in the thymus was not come back (Fig. 7). 


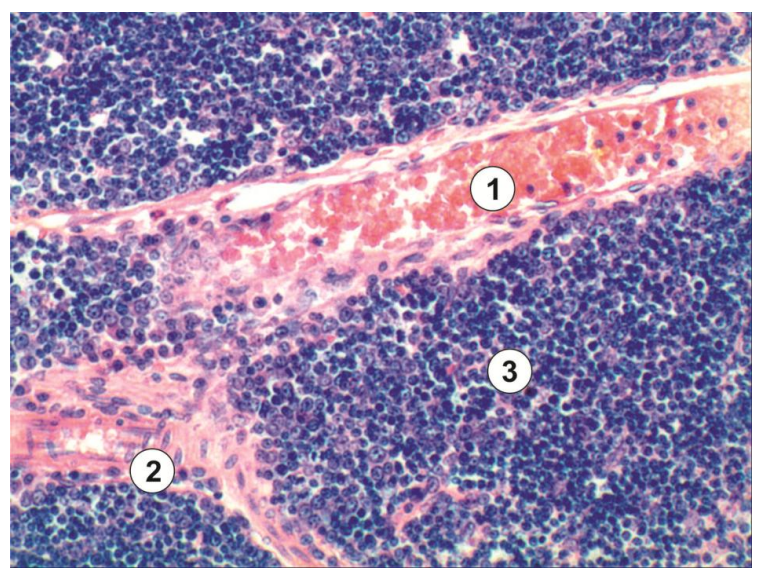

Fig. 5. Microscopic state of the cortex slices thymus ofanimals after three weeks of the experiment: expanded and filled withblood veins(1) composed of connective tissue partitions (2),

3 - Tlymphocytes. Stained with hematoxylin and eosin. Coll.: lens $\times 20$, glasses $\times 15$

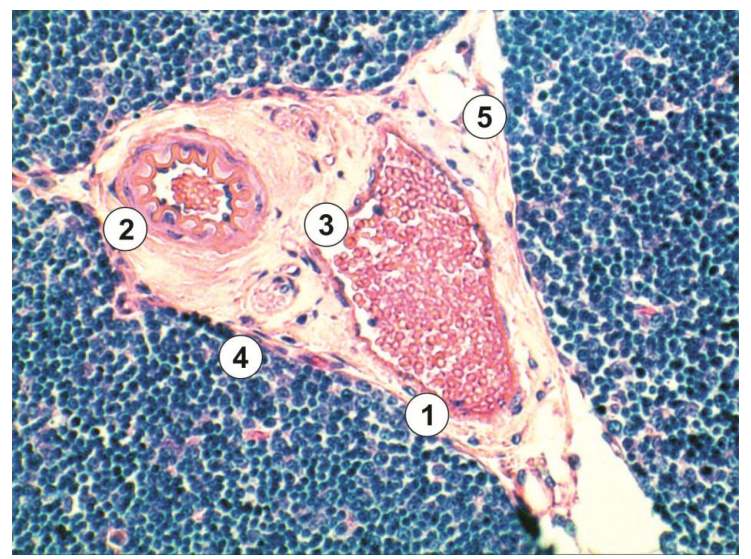

Fig. 6. Microscopic changes in the thymus cortex slices of animals after five weeks of experiment: plot interlobular connective tissue (1), interlobular artery with thickened wall (2) and filled with blood vein (3); perivascular edema(4); 5 - Tlymphocytes. Stained with hematoxylin and eosin. Coll.: lens $\times 20$, glasses $\times 15$

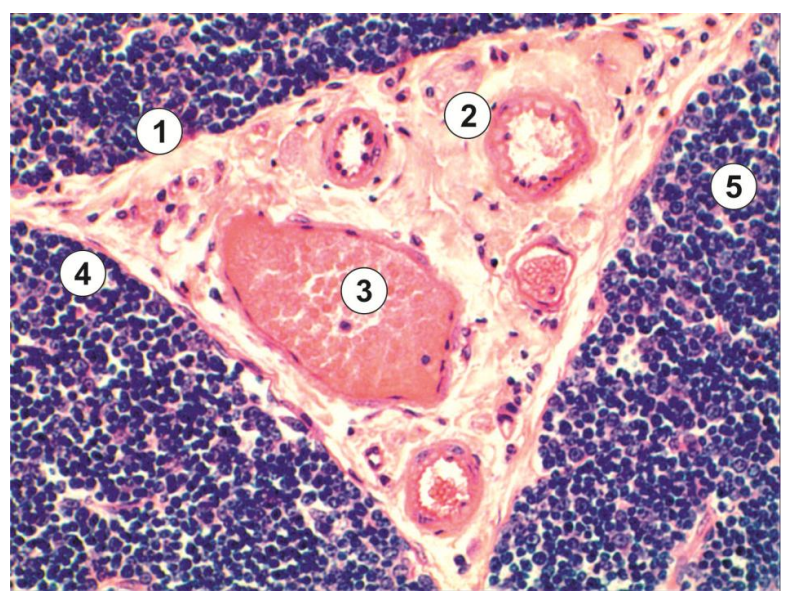

Fig. 7. Microscopic changes in the thymic cortex slices of animals in one week after discontinuation of the drug: plot thickened interlobular connective tissue (1); expanded artery

(2) and filled with blood vein (3); perivascular edema (4); 5 - Tlymphocytes. Stained with hematoxylin and eosin Coll.: lens $\times 20$, glasses $\times 15$ 


\section{Discussion}

At the one-week opioid nalbuphine exposure to male rats of reproductive age the was significantly increased the outer diameter of arteries of medium caliber 5,1\% and 3,3\% inner diameter. After 2 weeks, the external diameter decreases by $0,6 \%$ and the internal diameter by $0,8 \%$. After 3 weeks of daily administration of nalbuphine outer diameter decreases by $0,4 \%$ and an internal diameter by $12,5 \%$, due to the swelling of endothelial cells. Within 4 weeks of the experiment is the growth of the external diameter of the arteries by 3,6\%, but inside diameter further reduced (to $0,9 \%$ ). After 5 weeks of the experiment the outer diameter increases (2,5\%) and domestic one (3,4\%). This can be explained by the loosely placed fibers of connective tissue, edema and sclerosis. After 6 weeks of daily administration of opioid indicator external diameter decreases by $0,6 \%$ and domestic by $6,9 \%$. After 1 week after discontinuation of the drug outside diameter arteries decreased by $5,3 \%$ and is higher than this indicator in intact animals of $4,3 \%$, and the inner diameter is reduced slightly (by 0,2\%) and is lower than in intact animals to 14,8 \% (Table 2, Fig. 1).

After a week of opioid nalbuphine action in the body of male rats of reproductive age significantly $(\mathrm{p}<0,05)$ increases the average area of membrane (media) medium caliber arteries by $9,2 \%$ and lumen area by $6,2 \%$. After 2 weeks, media area increased by $1,4 \%$ and lumen area by $0,9 \%$. After 3 weeks of daily administration of nalbuphine media area increased by $2,6 \%$ and the lumen area decreased by $2 \%$. Within 4 weeks of the experiment area media increased by $6,1 \%$, due to the thickness of basement membrane, lumen area decreased by 1,5\%. After 5 weeks of the experiment the area of media increases (1,7\%) and lumen area (by 2,1\%). After 6 weeks of daily administration of opioid media area index decreased by $1,2 \%$ and lumen area by $0,9 \%$. After 1 week after discontinuation media area decreased by 3,2\% and is higher than this indicator in intact animals of 17,4 \% and lumen area decreased slightly (by $0,6 \%$ ) and is lower than in intact animals $4 \%$ (Table 3, Fig. 2).

These structural changes in the walls of arteries medium caliber prove the dynamics of Vohenvorta ratiochange(Table 3, Fig. 3).

\section{Conclusions}

As a result, the impact of opioid nalbuphine on male rats of reproductive age for six weeks revealed:

1) increased external diameter arteries of medium caliber $10.1 \%$;

2) reduced internal diameter arteries of medium caliber $14.6 \%$;

3) increased area of media medium caliber arteries by $21.3 \%$;

4) increased area of the lumen of medium caliber arteries by $4.7 \%$;

5) Vohenvorta ratio increased by $11.3 \%$;

6) gradual increase in the area of media medium caliber arteries thymus with maximum 5 weeks by $22 \%$. Then the media area begins to decrease;

7) the blood vessels are dilated, gaps filled with elements of the blood vessels around the swelling;

8) the process of sclerosis of blood vessels and circulatory hypoxia.

After one week after discontinuation of the drug:

1) the outer diameter of the arteries decreases, but remains higher than the indicator in intact animals of $4.3 \%$;

2) internal diameter decreases, but remains lower than in intact animals to $14.75 \%$; lumen area decreases, but remains lower than in intact animals by $4 \%$;

3) the area of media medium caliber arteries thymus begins to decrease but is higher by $17,4 \%$ than in intact animals.

\section{References}

[1] Davidovich, O. V., Kopcha, V. S., Masliy, K. O. (2011). Pharmacotherapy of pain. Rational pharmacotherapy, 4 (21), 66-68.

[2] Unexplained illness and death among injecting-drug users-Glasgow, Scotland; Dublin, Ireland; and England, April-June 2000 (2000). Morbid. Mortal. Wkly Rep, 49, 489-492. 
[3] Deeva, T. V., Maslovsky, S. U. (1999). Effect of Levamisol on morphological changes in thymus, bone marrow and spleen of rats. Journal of Morphology, 5 (1), 37-38.

[4] McCarthy, L., Wetzel, M., Sliker, J. K., Eisenstein, T. K., Rogers, T. J. (2001). Opioids, opioid receptors, and the immune response. Drug and Alcohol Dependence, 62 (2), 111-123. doi: 10.1016/s03768716(00)00181-2

[5] Smith-Slatas, C. L. (2006). Clostridium septicum Infections in Children: A Case Report and Review of the Literature. Pediatrics, 117 (4), e796-e805. doi: 10.1542/peds.2005-1074

[6] Díaz, F., Villena, A., Vidal, L., Moreno, M., García-Campos, J., de Vargas, I. P. (2010). Experimental Model of Ocular Hypertension in the Rat: Study of the Optic Nerve Capillaries and Action of Hypotensive Drugs. Investigative Opthalmology \& Visual Science, 51 (2), 946. doi: 10.1167/iovs.09-3667

[7] Cherkasov, E. V. (2012). The ultrastructure of thymic dendritic cells in experimental burn disease in rats and under the conditions of combined treatment hyperosmolar solutions. Bulletin morphology, 18 (1), 6-10.

[8] Lee, A. V., Kashchenko, S. A., Zakharov, A. A. (2009). Features of thymus structure of experimental animals after imunofan administration.Ukrainian medical almanac, 12 (1), 33-34.

[9] Nakahara, T., Uchi, H., Lesokhin, A. M., Avogadri, F., Rizzuto, G. A., Hirschhorn-Cymerman, D. et. al (2010). Cyclophosphamide enhances immunity by modulating the balance of dendritic cell subsets in lymphoid organs. Blood, 115 (22), 4384-4392. doi: 10.1182/blood-2009-11-251231

[10] Prakash, Gupta, V., Singh, S. M., Singh, M. P., Singh, G. (2007). Effect of Intrauterine Exposure of Murine Fetus to Cyclophosphamide on Development of Thymus. Immunopharmacology and Immunotoxicology, 29 (1), 17-30. doi:10.1080/08923970701277635

[11] Gorlov, N. V., Kashchenko, S. A., Zakharov, A. A. (2009). Morphological features of thymusstructure of immaturerats after cyclophosphanum introduction. Ukrainian medical almanac, 12 (1), 23-24.

[12] Zakharov, A. A. (2009). Morphological changes of thymus structure of immature rats after imunofan administration. Ukrainian medical almanac, 12 (1), 66-67.

[13] Kashchenko, S. A. (2003). Features ultramykroskopyc structure thymus gland of administering a rat after cyclophosphamide. Ukrainian medical almanac, 6 (3), 66-69.

[14] Kashchenko, S. A., Zakharov, A. A. (2008). Changes of thymus structure of mature white rats after cyclophosphanum application. Macedonian journal of medical sciences, 1, S36.

[15] Lee, A. V., Zakharov, A. A., Kashchenko, S. A. (2008). Morphological changes of structure of thymus and features of indexes of peripheral blood of mature rats after introduction of cyclophosphan. Ukrainian medical almanac, 11 (1), 186-187.

[16] Diskovskyi, I. S. (2014). Features of the reparative process under influence of opioid in experiment. RECOOP 5 thTriNet Meeting Wroclaw, 60.

[17] Mateschuk-Vatseba, L. R., Diskovskyy, S.(2014). Ultrastructural changes of rat skin during prolonged exposure to opioid. Bulletin of Ukrainian Medical Dental Academy «Actual problems of modern medicine.», 14 (4), 205-208.

[18] Pidvalna, U. Y. (2014). Influence of opioid on the condition of the uvea in the course of the experiment. RECOOP 5th TriNet Meeting Wroclaw.Wroclaw, 53.

[19] Onysko, R. M., Paltov, E. V., Fic, V. B., Vilhova, I. V., Kryvko, U. Y., Jakymiv, N. Y., Fitkalo, A. S. (2012). Pat. 76564 U Ukraine, IPC F 61 K 31/00 Method simulation of physical opioid dependence in rats. № u201207124; appl. 12.06.2012; publ. 01/10/2013. Bull. № 1 .

[20] Evropejs'ka konvencija pro zahist hrebetnih tvarin, shho vikoristovujut'sja dlja doslidnih ta inshih naukovih cilej (1986). Verhovna Rada Ukrai’ny. Available at: http://zakon4.rada.gov.ua/laws/show/994_137

[21] Jevropejs'kyj Parlament ta Rada Jevropejs'kyh spivtovarystv (2004). Verhovna Rada Ukrai'ny. Availalbe at:http://zakon4.rada.gov.ua/laws/show/994_961

[22] Pro zahyst tvaryn vid zhorstokogo povodzhennja (2006). Verhovna Rada Ukrai'ny. Available at: http://zakon3.rada.gov.ua/laws/show/3447-15 